\title{
IDENTIFIKASI PERMASALAHAN PETERNAKAN LEBAH MADU Apis mellifera di PATI, JAWA TENGAH
}

\author{
Puji Akhiroh1 ${ }^{1^{*}}$, Dewi Masyithoh2 ${ }^{2}$ \\ ${ }^{1}$ Fakultas Peternakan, Universitas Brawijaya, Indonesia \\ ${ }^{2}$ Fakultas Peternakan, Universitas Islam Malang, Indonesia \\ ${ }^{*}$ Corresponding E-mail: pujiakhiroh@ub.ac.id
}

\begin{abstract}
ABSTRAK
Tujuan penelitian ini adalah untuk mengidentifikasi permasalahan peternakan lebah madu Apis mellifera yang dihadapi oleh peternak di Kecamatan Gunungwungkal, Pati, Jawa Tengah. Penelitian ini dilakukan dengan menggunakan metode wawancara secara langsung terhadap 15 orang peternak lebah madu Apis mellifera yang terdapat di daerah Pati, Provinsi Jawa Tengah. Data hasil identifikasi permasalahan yang diperoleh dianalisis secara deskriptif. Hasil penelitian menunjukkan bahwa peternak lebah madu Apis mellifera di daerah Pati, Jawa Tengah memiliki permasalahan yang sama yaitu tentang pakan lebah berupa terbatasnya tanaman pakan lebah yang dapat berbunga sepanjang tahun dan paceklik pakan ketika musim hujan. Selain itu, masalah lainnya adalah penyakit atau hama yang menyerang peternakan lebah madu Apis mellifera berupa kutu (varroa destructor), keterbatasan lahan untuk angon lebah, terbatasnya jumlah ratu lebah yang berkualitas, proses budidaya yang tidak terkontrol, dan pemasaran produk madu. Dapat disimpulkan bahwa permasalah peternakan lebah madu Apis mellifera di Kecamatan Gunungwungkal, Pati, Jawa Tengah teridiri dari masalah pakan, penyakit, lahan, ratu lebah, pemeliharaan, dan pemasaran produk madu.
\end{abstract}

Kata Kunci: pakan lebah; madu; ratu lebah; budidaya

\section{INDETIFICATION OF BEEKEEPING PROBLEMS OF HONEYBEE Apis mellifera IN PATI, CENTRAL JAVA}

\begin{abstract}
ABSCTRACT
The aim of this study was to identify the beekeeping problems from beekeepers of Apis mellifera in District of Gunungwungkal, Pati, Central Java. This study was done with directly interview on 15 beekeepers of Apis mellifera in Pati, Central Java. The results showed that the beekeepers of Apis mellifera in Pati region, Central Java had the same problems were plants as the feed sources of the bees especially the limited of plants that can be blooming all year and the famine of feed in the rain season. In addition, the other problems were the disease or pest in like varoa, the limited of land for beekeeping, the quality of queen bee was limited, uncontrolled beekeeping process, and marketing of honey products. It can be concluded that the beekeeping problems from beekeepers in district of Gunungwungkal, Pati, Central Java were plant feed, disease or pest, area for beekeeping, queen bee, beekeeping process, and marketing of honey product.
\end{abstract}

Keywords: bee feed; honey; queen bee; beekeeping

\section{PENDAHULUAN}

Budidaya lebah madu khususnya lebah Apis mellifera telah lama dilakukan di Indonesia dan menjadi sumber pendapatan utama bagian sebagian masyarakat yang terlibat dalam proses budidayanya. Budidaya lebah madu Apis mellifera banyak dilakukan oleh peternak lebah di daerah Jawa yaitu di jawa Barat, Jawa Tengah, dan Jawa Timur. Lebah Apis mellifera menghasilkan beberapa produk yaitu madu, bee pollen, bee bread (roti lebah), propolis, dan royal jeli. Selain itu, juga banyak kalangan praktisi yang memanfaatkan sengat lebah sebagai salah satu metode terapi terhadap suatu penyakit. Widiarti dan Kuntadi (2012) menjelaskan bahwa lebah madu Apis mellifera di Indonesia pertama kali didatangkan dari Australia pada tahun 1970-an yang diprakarsai oleh Pusat Apiari Pramuka. Tahun 1974 didatangkan 20 kotak 
lebah Apis mellifera sebagai hadiah kunjungan presiden Soeharto ke Australia yang diserahkan kepada Gerakan Pramuka.

Lebah madu Apis mellifera tersebut terus berkembang sampai sekarang mulai dari peternakan yang masih bersifat tradisional, semi modern, dan bahkan modern. Budidaya lebah Apis mellifera kebanyakan sudah menggunakan stup yang dapat memberikan kemudahan dalam proses penanganan dan pengontrolan perkembangan koloni. Usaha budidaya lebah madu Apis mellifera harus didukung oleh ketersediaan tanaman pakan sumber nektar dan polen yang cukup banyak dan seimbang, sehingga dapat meningkatkan produktivitas lebah madu dalam memproduksi madu, bee pollen, bee bread, dan royal jeli. Pakan lebah berupa nektar dapat diperoleh dari bunga tanaman (flora nectar) dan bagian lain tanaman seperi pada ketiak dan tangkai daun (extraflora nectar) yang digunakan oleh lebah pekerja sebagai bahan baku untuk memproduksi madu. Pakan lebah lainnya berupa tepung sari atau polen yang dapat diperoleh dari bunga tanaman. Tepung sari atau polen tersebut merupakan sumber protein utama bagi lebah madu dan sebagai bahan baku untuk memproduksi bee bread (roti lebah) dan royal jeli (Agussalim et al., 2018; 2017).

Usaha budidaya lebah madu Apis mellifera yang dilakukan oleh peternak di lapangan banyak menghadapi beberapa masalah. Widiarti dan Kuntadi (2012) melaporkan bahwa masalah yang dihadapi oleh peternak lebah madu Apis mellifera di Kecamatan Gembong, Pati, Jawa Tengah berdasarkan tingkat urgensi masalah tersebut dari skala prioritas tertinggi ke terrendah terdiri dari pakan sebesar $78,13 \%$, dana atau modal usaha/kerja $59,38 \%$, pembinaan teknis $37,50 \%$, penyuluhan $50,00 \%$, hama atau penyakit $18,75 \%$, dan ketersediaan bibit khususnya bibit lebah ratu yang berkualitas sebesar 25,00\%. Lebih lanjut, Saepudin (2015) melaporkan bahwa tingkat urgensi permasalahan budidaya lebah madu Apis cerana atau Apis dorsata di Provinsi Bengkulu dari terbesar ke yang terkecil berturut-turut kualitas bibit atau ratu lebah sebesar 70,19\%, dana atau modal sebesar 48,34\%, pembinaan sebesar 45,40\%, penyuluhan $27,20 \%$, dan teknologi sebesar 22,07\%. Masalah yang dihadapi oleh peternak lebah madu Apis mellifera dari tahun ke tahun cukup bervariasi. Dengan demikian, diperlukan penelitian lebih lanjut, terkait identifikasi permasalahan peternakan lebah madu Apis mellifera di Kecamatan Gunungwungkal, Pati, Jawa Tengah.

\section{MATERI DAN METODE}

Penelitian ini melibatkan 15 peternak lebah madu Apis mellifera di Kecamatan Gunungwungkal, Pati, Jawa Tengah. Peternak tersebut di wawancara dan observasi secara langsung (Singarimbun dan Sofian, 1982) terkait masalah yang dihadapinya selama proses budidaya lebah di lapangan. Data yang diperoleh tersebut dianalisis secara deskriptif.

\section{HASIL DAN PEMBAHASAN}

Budidaya lebah madu Apis mellifera kebanyakan dilakukan di Jawa yang sebagian besar tersebar di Jawa Timur dan Jawa Tengah, termasuk daerah Pati. Masalah yang dihadapi oleh peternak lebah madu Apis mellifera di Kecamatan Gunungwungkal Pati, Jawa Tengah dan solusi permasalahan hasil penelitian dapat dilihat pada Tabel 1.

Tabel 1. Masalah yang dihadapi ole peternak lebah madu Apis mellifera dan solusi permasalahannya

\begin{tabular}{cc}
\hline Uraian Masalah & Solusi Permasalahan \\
\hline Pakan & Pada musim paceklik pakan harus diberi makan air gula \\
Penyakit & Apabila ada kutu (varroa destructor) harus segera diberi obat yang \\
Lahan & mengandung bahan aktif fluvalinate, amitraz, dan asam format \\
Ratu lebah & Harus sewa lahan \\
Pemeliharaan & Membuat sendiri \\
Pemasaran & Dikontrol seminggu sekali \\
\end{tabular}




\section{Permasalahan Peternak Lebah}

Hasil penelitian menunjukkan bahwa permasalahan yang dihadapi oleh 15 orang peternak lebah madu Apis mellifera di Kecamatan Gunungwungkal, Pati, Jawa Tengah terdiri dari masalah pakan, penyakit, lahan, ratu lebah, pemeliharaan, dan pemasaran produk madu (Tabel 1). Pakan merupakan salah satu faktor yang sangat penting dalam budidaya lebah madu secara umum termasuk lebah Apis mellifera yang dibudidayakan oleh peternak di Kecamatan Gunungwungkal, Pati, Jawa Tengah. Sumber pakan bagi lebah madu adalah nektar dan polen yang berasal dari bunga tanaman yang tumbuh disekitar lokasi budidaya. Nektar merupakan cairan manis yang berasal dari kelenjar nektaris tanaman yang dapat berkembang pada bagian bunga (flora nectar) dan nektar ekstraflora (extraflora nectar) yang dapat berkembang pada bagian selain bunga yaitu ketiak dan tangkai daun tanaman (Agussalim et al., 2018; 2017; Pacini dan Nicolson, 2007). Polen merupakan alat kelamin jantan bunga tanaman, dimana polen atau tepung sari tersebut merupakan sumber protein yang utama bagi lebah madu termasuk lebah Apis mellifera. Polen tersebut sangat dibutuhkan oleh lebah madu karena sebagai bahan baku dalam pembuatan royal jeli yang dilakukan oleh lebah pekerja sebagai makanan lebah ratu sehingga dapat meningkatkan produktivitas lebah ratu dan dapat menghasilkan koloni super yang sehat (Abrol, 2011; Sihombing, 2005). Ketersediaan pakan lebah sumber nektar dan polen yang cukup, seimbang dan berkelanjutan merupakan salah satu faktor yang dapat meningkatkan produktivitas koloni lebah dalam memproduksi madu dan bee bread (roti lebah) serta akan menentukan tingkat keberhasilan dan keberlanjutan usaha budidaya lebah madu secara umum, termasuk lebah Apis mellifera (Agussalim et al., 2018; 2017).

Keterbatasan tanaman pakan yang dapat berbunga sepanjang tahun di Kecamatan Gunungwungkal, Pati, Jawa Tengah menjadi masalah yang sangat besar bagi keberlanjutan produksi madu, bee pollen, dan royal jeli. Selain itu, kekurangan pakan lebah atau paceklik pakan terjadi ketika musim hujan, karena sangat sedikit tanaman yang dapat berbunga dan ketika tanaman tersebut berbunga nektarnya akan dibilas oleh air hujan, sehingga nektar tersebut tidak dapat dikumpulkan oleh lebah madu. Widiarti dan Kuntadi (2012) melaporkan bahwa sebagian permasalahan utama yang dihadapi oleh peternak lebah madu Apis mellifera yang terdapat di Kecamatan Gembong, Kabupaten Pati, Jawa Tengah yaitu masalah pakan sebesar $78,13 \%$. Salah satu jenis, tanaman pakan yang sudah langka adalah tanaman kapuk randu sebagai sumber nektar dan polen bagi lebah madu, akan tetapi jumlah tanaman kapuk randu di daerah Pati, Jawa Tengah semakin menurun. Penurunan tersebut diduga berkaitan dengan banyaknya masyarakat yang beralih dari bahan baku kasur berasal dari kapuk randu ke bahan busa, sehingga banyak kapuk randu yang ditebang akibat permintaannya yang rendah.

Dalam budidaya lebah madu Apis mellifera tidak terlepas dari masalah hama dan penyakit yang dapat merusak perkembangan koloni di dalam sarang. Hasil penelitian menunjukkan bahwa penyakit yang banyak dihadapi oleh peternak lebah Apis mellifera di Kecamatan Gunungwungkal, Pati, Jawa Tengah adalah penyakit kutu yang disebabkan oleh varroa destructor dan biasanya peternak lebah Apis mellifera segera memberi obat yang mengandung bahan aktif fluvalinate, amitraz, dan asam format untuk mengendalikan kutu tersebut. Widiarti dan Kuntadi (2012) melaporkan bahwa hama utama yang menyerang peternakan lebah madu Apis mellifera adalah varroa destructor yaitu sebesar $18,75 \%$. Kuntadi dan Andadari (2013) melaporkan bahwa Indonesia mengalami ledakan serangan dari varroa destructor sekitar pertengahan tahun 1990-an yang menyebabkan musnahnya populasi lebah madu Apis mellifera sekitar 50-60\% dari populasi. Lebih lanjut, Widiarti dan Kuntadi (2012) menjelaskan bahwa masalah hama varroa destructor tersebut, peternak lebah Apis mellifera di Kecamatan Gembong, Pati, Jawa Tengah melakukan pengobatan secara rutin menggunakan kombinasi antara naphthalene dan belerang serta beberapa jenis obat pembasmi hama pertanian lainnya.

Dalam budidaya lebah madu Apis mellifera harus memiliki dan memerlukan lahan yang cukup luas sebagai lokasi untuk menanam tanaman pakan dan sebagai lokasi untuk meletakkan koloni lebah yang dibudidayakan. Akan tetapi, kondisi atau keadaan tersebut berbanding terbalik dengan kondisi peternak lebah Apis mellifera di Indonesia, termasuk di Kecamatan Gunungwungkal, Pati, Jawa Tengah yang rata-rata tidak memiliki lahan perkebunan. Akibatnya, peternak lebah tersebut hanya mengandalkan lahan kosong yang 
berada disekitar lokasi pekebunan dan ada juga yang melakukan penyewaan lahan. Pemanfaatan lahan kosong yang berdekatan dengan area perkebunan buah juga tidak terlepas dari masalah yang dihadapi oleh peternak lebah Apis mellifera. Widiarti dan Kuntadi (2012) melaporkan bahwa masih adanya penolakan yang dilakukan oleh pemilik kebun dengan adanya koloni lebah Apis mellifera disekitar perkebunannya. Mereka beranggapan bahwa lebah tersebut merupakan penyebab rontoknya bunga tanaman buah di area pekerbunan mereka, sehingga produktivitasnya menurun. Lebih lanjut, dilaporkan bahwa penolakan yang dilakukan oleh pemilik kebun tersebut adalah adanya ancaman bahwa mereka akan membakar stup-stup lebah dan bahkan stup lebah Apis mellifera dijungkirbalikkan.

Salah satu upaya yang dapat dilakukan untuk meningkatkan produktivitas lebah madu Apis mellifera adalah menyediakan lebah ratu yang berkualitas yang ditandai dengan produktivitas tinggi dalam mengasilkan telur, terutama telur sebagai lebah pekerja. Jumlah lebah pekerja tersebut akan sangat berpengaruh terhadap produksi madu, bee pollen, bee bread (roti lebah), propolis dan royal jeli yang dihasilkan dalam suatu usaha budidaya lebah madu. Akan tetapi, ketersediaan ratu yang berkualitas tersebut menjadi masalah bagi peternak lebah madu Apis mellifera yang terdapat di Kecamatan Gunungwungkal, Pati, Jawa Tengah hasil penelitian (Tabel 1). Widiarti dan Kuntadi (2012) melaporkan bahwa masalah yang dihadapi oleh peternak lebah madu Apis mellifera yang terdapat di Kecamatan Gembong adalah kualitas lebah ratu yaitu sekitar $25 \%$. Lebih lanjut, dijelaskan bahwa peternak menyadari bahwa lebah ratu yang berkualitas sangat berpengaruh terhadap produktivitas dan perkembangan jumlah koloni, akan tetapi lebih pada ketersediaan pakan yang berkelanjutan terutama sumber nektar dan polen dalam jumlah yang cukup dan seimbang. Selain itu, peternak lebah madu Apis mellifera memiliki kemampuan melakukan penangkaran sendiri lebah ratu yang biasa dilakukan dengan metode grafting. Lebih lanjut, kerjasama antar sesama peternak dalam perbanyakan lebah ratu yang berkualitas juga dapat menjadi salah satu solusi dalam mengatasi permasalahan ketersediaan ratu lebah yang berkualitas. Saepudin (2015) melaporkan bahwa tingkat urgensi permasalahan yang tertinggi adalah bibit atau kualitas ratu lebah untuk peternakan lebah madu Apis cerana atau Apis dorsata di Bengkulu yaitu sebesar $70,19 \%$ dan ini merupakan urgensi masalah yang paling utama. Hal tersebut, diduga karena pada lebah Apis cerana atau Apis dorsata belum dapat diproduksi ratu lebah seperti produksi ratu lebah Apis mellifera dengn metode grafting.

Masalah yang sering dihadapi ketika proses budidaya atau pemeliharaan lebah madu Apis mellifera yang sering diabaikan adalah kurangnya perhatian peternak dalam mengontrol kondisi perkembangan koloninya. Akan tetapi, masalah pemeliharaan ini tidak termasuk dalam kategori masalah yang sangat serius selain ketersediaan pakan lebah yang berkelanjutan, penyakit varroa destructor, ketersediaan lahan sebagai lokasi angon dan untuk menanam tanaman pakan lebah. Ketika produk madu lebah Apis mellifera telah dipanen dan dikemas yang salah satunya adalah masalah dalam pemasaran produknya. Hal tersebut diduga karena keterbatasan peternak dalam mengakses pasar, melakukan promosi, pengetahuan akan strategi pemasaran produknya, desain atau kemasan yang kurang menarik. Akibatnya, produk madu tersebut tidak laku dipasaran karena kalah bersaing dengan madu-madu yang sudah memiliki branding yang cukup terkenal di kalangan konsumen. Widiarti dan Kuntadi (2012) melaporkan bahwa peternak lebah Apis mellifera menempatkan masalah dalam skala priotitas dari yang terbesar sampai kepada yang terkecil terdiri dari pakan sebesar $78,13 \%$, dana atau modal usaha/kerja $59,38 \%$, pembinaan teknis $37,50 \%$, penyuluhan $50,00 \%$, hama atau penyakit $18,75 \%$, dan ketersediaan bibit khususnya bibit lebah ratu yang berkualitas sebesar 25,00\%. Lebih lanjut, Saepudin (2015) melaporkan bahwa tingkat urgensi permasalahan budidaya lebah madu Apis cerana atau Apis dorsata di Provinsi Bengkulu dari terbesar ke yang terkecil berturut-turut kualitas bibit atau ratu lebah sebesar $70,19 \%$, dana atau modal sebesar $48,34 \%$, pembinaan sebesar $45,40 \%$, penyuluhan $27,20 \%$, dan teknologi sebesar $22,07 \%$.

\section{Solusi Permasalahan Peternak}

Beberapa solusi dari permasalahan yang dihadapi oleh peternak lebah madu Apis mellifera yang terdapat di Kecamatan Gunungwungkal, Pati, Jawa Tengah dapat dilihat pada Tabel 1. Untuk masalah kelangkaan pakan ketika musim hujan atau musim paceklik pakan 
dapat dilakukan dengan memberikan pakan tambahan seperti gula yang dilarutkan dengan air. Air gula tersebut diberikan ke lebah dengan memasukkannya ke dalam feeder frame (bingkai khusus untuk pakan), sehingga memudahkan lebah tersebut untuk menyedot cairan gula tersebut. Hal ini sesuai dengan laporan Widiarti dan Kuntadi (2012), bahwa subsidi gula yang diharapkan oleh peternak lebah Apis mellifera di Kecamatan Gembong, Pati, Jawa Tengah sebesar $50 \%$, akan tetapi lebih rendah apabila dibandingkan dengan kawasan yang ditanami dengan tanaman pakan lebah yaitu sebesar $87,50 \%$.

Untuk masalah penyakit varroa destructor dapat diatasi dengan pemberian obat kutu yaitu obat yang mengandung bahan aktif fluvalinate, amitraz, dan asam format sehingga mengendalikan kutu tersebut. Widiarti dan Kuntadi (2012) melaporkan bahwa peternak lebah madu Apis mellifera di Kecamatan Gembong, Pati, Jawa Tengah biasa memberikan kombinasi antara naphthalene dan belerang serta beberapa jenis obat pembasmi hama pertanian lainnya. Keterbatasan kepemilikan lahan oleh peternak lebah madu Apis mellifera dapat diatasi dengan menyewa lahan yang terletak disekitar area pekerbunan dengan harapan akan memberikan kemudahan lebah pekerja dalam memperoleh pakan berupa nektar sebagai bahan baku untuk memproduksi madu dan polen sebgaai bahan baku untuk memproduksi bee bread (roti lebah). Lahan yang disewa tersebut dapat berasal dari lahan masyarakat perorangan ataupun lahan milik pemerintah. Widiarti dan Kuntadi (2012) melaporkan solusi yang diharapkan oleh peternak lebah madu Apis mellifera di Kecamatan Gembong, Pati, Jawa Tengah terkait dengan masalah lahan yaitu aturan penebangan tanaman pohon tegakan sebesar $18,75 \%$ terutama sebagai sumber nektar dan polen, aturan angon lebahnya sebesar $25 \%$, dan kawasan yang ditanami dengan pakan lebah sumber nektar dan polen sebesar $87,50 \%$.

Ratu lebah yang tidak berkualitas dapat diatasi dengan melakukan penangkaran ratu lebah yang berasal dari telur lebah yang umurnya tidak lebih dari 1 hari dan berasal dari koloni super dengan harapan dapat mengikuti produktivitas tetua atau induknya. Widiarti dan Kuntadi (2012) melaporkan bahwa solusi yang dihadapi oleh peternak lebah madu Apis mellifera di Kecamatan Gembong, Pati, Jawa Tengah untuk mengatasi ratu lebah yang tidak berkualitas adalah adanya subsidi bibit lebah sebesar $18,75 \%$. Masalah dalam pemeliharaan dapat lebah dapat diatasi dengan melakukan pengontrolan rutin sekali seminggu terkait perkembangan koloni lebah dan pengecekan hama atau penyakit. Selain itu, Widiarti dan Kuntadi (2012) melaporkan bahwa solusi dari permasalahan yang diharapkan oleh peternak lebah di Kecamatan Kembong, Pati, Jawa Tengah adalah adanya subsidi peralatan yang akan digunakan dalam proses budidaya, panen, pemerasan madu, dan pascapanen.

Lebih lanjut, solusi bagi permasalahan pemasaran produk madu yang dihasilkan oleh peternak lebah Apis mellifera di Kecamatan Gunungwungkal, Pati, Jawa Tengah adalah terkait pemasaran produk madu. Solusi yang dapat mengatasi masalah tersebut adalah dengan menjual secara langsung madu ke pengepul dengan memperhatikan dan merujuk kepada standar-standar tertentu yang telah ditetapkan oleh pengepul, misalnya berkaitan dengan kadar air dari madu yang telah dipanen. Lebih lanjut, Widiarti dan Kuntadi (2012) melaporkan bahwa solusi yang diharapkan oleh peternak lebah madu Apis mellifera di Kecamatan Gembong, Pati, Jawa Tengah adalah adanya standarisasi harga produk madu sebesar 31,25\%. Standar harga tersebut akan sangat bermanfaat bagi peternak lebah agar tidak ditawar oleh pengepul dengan harga yang lebih rendah dari standar yang menyebabkan peternak tersebut merasa dirugikan. Dengan demikian, membangun hubungan dan kerjasama yang baik antar peternak lebah dengan pengepul atau perusahaan yang dapat menampung produk madu yang dihasilkan akan dapat meningkatkan pendapatan peternak lebah Apis mellifera di daerah Pati, Jawa Tengah.

\section{KESIMPULAN}

Beberapa masalah yang dihadapi oleh peternak lebah madu Apis mellifera di Kecamatan Gunungwungkal, Pati, Jawa Tengah terdiri dari keterbatasan pakan lebah sumber nektar dan polen yang berkelanjutan, adanya penyakit varroa destructor, keterbatasan kepemilikan lahan untuk angon dan menanam tanaman pakan lebah, kualitas lebah ratu yang rendah, kurangnya pengontrolan lebah selama proses pemeliharaan atau budidaya, dan akses pasar untuk pemasaran produk madu yang terbatas. 


\section{DAFTAR PUSTAKA}

Abrol, D.P. 2011. Foraging. In : Randall H. and SE. Radloff (eds). Honeybees of Asia pp. 257292. Springer, New York.

Agussalim, A. Agus, N. Umami, dan I G. S. Budisatria. 2017. The type of honeybees forages in District of Pakem Sleman and Nglipar Gunungkidul Yogyakarta. Buletin Peternakan. 42(1): 50-56

Agussalim, A. Agus, N. Umami, dan I G. S. Budisatria. 2017. Variasi jenis tanaman pakan lebah madu sumber nektar dan polen berdasarkan ketinggian tempat di Yogyakarta. Buletin Peternakan. 41(4): 448-460.

Kuntadi dan L. Andadari. 2013. Aktivitas akarisida beberapa minyak atsiri, insektisida nabati, dan cuka kayu terhadap Anderson \& Trueman (Acari: Varroidae) Varroa. Jurnal Penelitian Hutan Tanaman. 10(1): 33-42.

Pacini, E. and S.W. Nicolson. 2007. Introduction. In: W.N. Susan, M. Nepi and E. Pacini (eds.). Nectaries and Nectar. pp. 1-18. Springer, New York.

Saepudin, R. 2015. Identifikasi permasalahan perlebahan sebagai dasar pengembangan usaha madu di Provinsi Bengkulu. Jurnal Sain Peternakan Indonesia.10(1): 51-58

Sihombing, D.T.H. 2005. Ilmu Ternak Lebah Madu. Gadjah Mada University Press, Yogyakarta.

Singarimbun, M. dan E. Sofian. 1982. Metoda Penelitian Survai. Jakarta: LP3ES.

Widiarti, A. dan Kuntadi. 2012. Budidaya lebah madu Apis mellifera L. oleh masyarakat pedesaan Kabupaten Pati, Jawa Tengah. Jurnal Penelitian Hutan dan Konservasi Alam. 9(4): 351-361 